\title{
HUBUNGAN ANTARA ANTENATAL CARE, HIPERTENSI DALAM KEHAMILAN, DAN RIWAYAT PENYAKIT IBU DENGAN STATUS GIZI IBU HAMIL DI PUSKESMAS GANDUS PALEMBANG TAHUN 2016
}

\author{
Rizki Amalia \\ Yulisa Maulia \\ Universitas Kader Bangsa Palembang
}

Informasi Artikel :

Diterima : $\quad$ September 2018

Disetujui : $\quad$ November 2018

"Korespondensi Penulis : ramdhanilist@gmail.com

\begin{abstract}
A B S T R A K
Status gizi merupakan ukuran keberhasilan dalam pemenuhan nutrisi untuk ibu hamil. Status gizi juga dapat diartikan sebagai status kesehatan yang dihasilkan oleh keseimbangan antara kebutuhan dan masukan nutrient. dampak atau bahaya status gizi ibu hamil yang buruk, baik sebelum kehamilan atau pada saat kehamilan akan mempengaruhi kondisi ibu dan janin. Tujuan penelitian ini adalah untuk mengetahui hubungan antara antenatal care, hipertensi dalam kehamilan, dan riwayat penyakit ibu dengan status gizi ibu hamil di puskesmas gandus palembang tahun 2016. Jenis penelitian ini menggunakan metode survei analitik dengan desain penelitian Cross Sectional. Populasi penelitian ini adalah semua ibu yang memeriksakan kehamilan di Puskesmas gandus Palembang dari bulan Agustus tahun 2016. sample yang diambil berjumlah 62 orang.Data yang disajikan dalam bentuk tabel distribusi responden dan dilakukan analisis univariat dan bivariat secara komputerisasi. hasil uji statistik menunjukkan bahwa hubungan antenatal care dengan status gizi diperoleh hasil uji Chi - Square diperoleh $p$ value $=0,03$ (bermakna), hubungan hipertensi dalam kehamilan dengan status gizi diperoleh hasil uji Chi Square diperoleh $p$ value $=0,068$ (tidak bermakna), riwayat penyakit ibu dengan status gizi diperoleh hasil uji Chi - Square diperoleh $p$ value $=0,153$ (tidak bermakna). Diharapkan hasil penelitian ini dapat dijadikan masukan baik dalam menyusun rencana strategi serta pelaksanaan dalam memberikan pelayanan langsung pada pasien, sehingga mutu dan kualitas pelayanan lebih ditingkatkan lagi
\end{abstract}

Kata Kunci : Status Gizi, ANC, Hipertensi Dalam Kehamilan, Dan Riwayat Penyakit Ibu

\begin{abstract}
Nutritional status assesses the nutrional fulfillment in pregnant women. It can also be defined as the indicator of health which is achieved by balancing between the needs and nutrient intake. Poor nutrional status can give negative impact on pregnancy, not only before but also during the pregnancy and it influences the condition of the mothers and their fetuses. This research aimed to investigate the association between antenatal care, hypertension in pregnancy, mother's medical history with nutrional status of pregnant woman in the Community Health Center of gandus, palembang in 2016. This research used analytical survey method with Cross-Sectional study designed. The research's population was all pregnant women who had antenatal care in the community health center of gandus in Agust 2016. The samples taken were 62 people. The data were presented in the table of distribution of respondents and analyzed using computerized univariate and bivariate techniques. The result of statistics test, using Chi-Square test showed that the association between antenatal care and nutrional status was significant with $p$-value $=0.03$, the association between hypertension in pregnancy and nutrional status was not significant with p-value $=0.068$, the association of mothers' medical history with nutrional status was not significant with $p$-value =
\end{abstract}


0.153. it is expected that the result of this research gives positive contribution in designing the strategic plan as well as implementing direct patient services in order to improve service quality.

Keywords : Nutritional Status, ANC, Hypertension In Pregnancy, And Mother' Medical History

\section{PENDAHULUAN}

World health organization (WHO) melaporkan bahwa prevalensi ibu hamil yang mengalami defisiensi besi sekitar 35-75\%. Angka ini meningkat seiring dengan pertambahan usia kehamilan. Anemia defisiensi zat besi merupakan masalah gizi yang paling lazim di dunia dan menjangkiti lebih dari 600 juta manusia. Perkiraan prevalensi anemia secara global sekitar $51 \%$ pada tahun 1990 (Rukiyah dan Yulianti, 2010).

Menurut studi yang dilakukan oleh Southeast Asia Food and Agricultural Science \& Technology (SEAFAST) Centre, Institut Pertanian Bogor (IPB) pada 2011, terhadap lebih dari 200 wanita hamil, memperlihatkan bahwa lebih dari $50 \%$ ibu hamil tersebut memiliki asupan gizi lebih rendah dari Angka Kecukupan Gizi (AKG) yang dianjurkan (Iswahyudi, 2015).

Empat masalah gizi utama di Indonesia adalah Kekurangan Energi Kronik (KEK), Gangguan Akibat Kekurangan Yodium (GAKY), Kekurangan vitamin A (KVA), dan Anemia Gizi Besi (AGB). Salah satu golongan rawan gizi yang menjadi sasaran program adalah remaja dan ibu hamil. Masalah yang banyak terjadi pada remaja dan ibu hamil adalah Anemia, defisiensi besi, dan kelebihan atau kekurangan berat badan (Sulistyoningsih, 2014).

Berdasarkan data dari Puskesmas Gandus Palembang diketahui bahwa jumlah ibu hamil yang memeriksakan kehamilan pada tahun 2013 adalah 1883 orang, terdiri dari 1715 orang (91\%) yang merupakan kehamilan normal tidak resiko kekurangan gizi dan 168 orang (9\%) yang mengalami resiko kekurangan gizi. Pada tahun 2014 adalah 1953 orang, yang tediri dari 1732 orang $(88,7 \%)$ tidak beresiko kekurangan gizi 221 orang $(11,3 \%)$ beresiko mengalami kekurangan gizi. Dan pada tahun 2015 adalah 1919 orang, yang tediri dari 1736 orang $(90,5 \%)$ ibu yang tidak beresiko kekurangan gizi dan 183 orang $(9,5 \%)$ ibu yang beresiko kekurangan gizi. Pada bulan Januari hingga bulan Agustus 2016 Ibu yang memeriksakan kehamilan di puskesmas gandus palembang berjumlah 1379 orang, terdiri dai 1250 orang $(90,6 \%)$ ibu hamil tidak beresiko kekurangan gizi dan 129 orang $(9,4 \%)$ ibu hamil yang mengalami resiko kekurangan gizi.

Status gizi merupakan ukuran keberhasilan dalam pemenuhan nutrisi untuk ibu hamil. Gizi secara langsung dipengaruhi oleh asupan makanan dan penyakit. Asupan gizi sangat menentukan kesehatan ibu hamil dan janin yang dikandungnya. Kebutuhan gizi pada masa kehamilan akan meningkat sebesar $15 \%$ dibandingkan dengan kebutuhan wanita normal. Ibu hamil memerlukan tambahan semua zat gizi. Zat gizi yang sering menjadi kekurangan pada ibu hamil adalah energi protein dan beberapa mineral seperti zat besi dan kalsium (Atika dan Siti, 2009).

Menurut Organisasi Kesehatan Dunia (WHO) Antenatal care untuk mendeteksi dini terjadinya risiko tinggi terhadap kehamilan dan persalinan juga dapat menurunkan angka kematian ibu dan memantau keadaan janin. Kurangnya pengetahuan saat hamil, dan kondisi kemiskinan ibu akan mengalami resiko kekurangan gizi, dapat beresiko bayi mengalami BBLR (Mutalazimah, 2005)

Hasil penelitian yang dilakukan Mardiatun dkk (2013) di Provinsi Nusa Tenggara Barat dan di Daerah Istimewa Yogyakarta menyatakan bahwa terdapat hubungan antara ANC dengan status gizi di NTB dengan nilai OR 1,793. Hasil uji statistik Chi Square didapatkan nilai $\mathrm{p}(0,000)<0,05$ sehingga terdapat hubungan antara ANC dengan status gizi di yogyakarta dengan nilai OR 0,442 .

Status gizi ibu hamil tercermin dari ukuran antropometrinya. Ukuran antropometri ibu hamil yang paling sering digunakan adalah kenaikan berat badan ibu hamil dan ukuran Lingkar Lengan Atas (LLA). Bila status gizi ibu sebelum hamil dalam kondisi baik maka ibu akan melahirkan bayi yang sehat, cukup bulan dan berat badannya normal (Atika dan Siti, 2009).

Nutrisi yang buruk pada kehamilan lanjut akan mempengaruhi pertumbuhan janin sehingga pertumbuhan janin tidak akan maksimal karena asupan nutrisi janin yang berasal dari ibu kurang (Atika dan Siti, 2009).

Berdasarkan uraian di atas, maka peneliti tertarik untuk melakukan penelitian ini dengan judul "Hubungan Antara Antenatal Care, Hipertensi Dalam Kehamilan, Dan Riwayat Penyakit Ibu 
Jurnal Kebidanan : Jurnal Medical Science Ilmu Kesehatan Akademi Kebidanan Budi Mulia Palembang Volume.8 No.2, Desember 2018

\section{dengan Status Gizi Ibu Hamil di Puskesmas Gandus Palembang Tahun 2016"}

\section{METODE PENELITIAN}

Desain penelitian ini menggunakan metode survei analitik dengan desain penelitian Cross Sectional, dimana data tentang variabel independen (antenatal care, hipertensi dalam kehamilan, dan riwayat penyakit ibu) dan variabel dependen (status gizi ibu hamil) diambil atau diukur dalam waktu bersamaan (Notoatmodjo, 2012).

Populasi adalah keseluruhan objek penelitian (Notoadmodjo, 2012). Populasi dalam penelitian ini adalah semua ibu yang memeriksakan kehamilan di Puskesmas gandus Palembang dari bulan Juli Agustus tahun 2016 sebanyak 62 orang.

Analisis Univariat ini digunakan untuk memperoleh gambaran distribusi frekuensi dan persentase dari semua variabel penelitian, yaitu antenatal care, hipertensi dalam kehamilan, dan riwayat penyakit ibu sebagai variabel independen dan status gizi ibu hamil sebagai variabel dependen.

Analisis Bivariat ini digunakan untuk mengetahui hubungan antara variabel independen dengan variabel dependen, sehingga diketahui apakah ada hubungan antara yaitu antenatal care, hipertensi dalam kehamilan, dan riwayat penyakit ibu dengan kejadian status gizi ibu hamil. Uji statistik yang digunakan dalam penelitian ini adalah uji chi square.

Batas kemaknaan yang digunakan dalam penelitian ini adalah $a=0,05$. Pengambilan keputusan statistik dilakukan dengan membandingkan nilai $p$ ( $p=$ value $)$ dengan nilai $a$ $(0,05)$, dengan ketentuan (Notoadmodjo, 2012).

\section{HASIL PENELITIAN}

1. Pelaksanaan Penelitian

Teknik pengumpulan data pada penelitian ini dilakukan dengan menggunakan data primer dan data sekunder. Data primer ialah yang dikumpulkan dengan cara wawancara berstruktur dengan menggunakan kuesioner. Data sekunder menggunakan ceklist dengan cara melihat buku KMS ibu hamil di puskesmas gandus palembang.

2. Penyajian Data

\section{a. Analisa Univariat}

Analisa ini untuk mengetahui distribusi frekuensi dan persentase dari tiap variabel independen (antenatal care, hipertensi dalam kehamilan dan riwayat penyakit ibu) dan variabel dependen (status gizi ibu hamil). Data distribusi dalam bentuk tabel dan teks akan diuraikan sebagai berikut:

\section{Gizi Ibu Hamil}

Gizi Ibu Hamil dikategorikan menjadi dua yaitu Standar (2 kategori yaitu : Gizi Baik (Bila LILA > 23,5 dan berat badan $\geq 10-12 \mathrm{~kg}$ ), dan Gizi Kurang (Apabila LILA < 23,5 $\mathrm{cm}, \mathrm{BB} \leq 10 \mathrm{Kg}$ ) dapat dilihat pada tabel 1:

Tabel 1 Distribusi Frekuensi Responden

Berdasarkan Kejadian Status

Gizi Di Puskesmas Gandus Palembang Tahun 2016

\begin{tabular}{llcc}
\hline No & Status Gizi & $\begin{array}{c}\text { Jumlah } \\
(\mathbf{n})\end{array}$ & $\begin{array}{c}\text { Persentase } \\
(\boldsymbol{\%})\end{array}$ \\
\hline $\mathbf{1}$ & Gizi baik & 43 & $69,4 \%$ \\
$\mathbf{2}$ & Gizi buruk & 19 & $30,6 \%$ \\
\hline Jumlah & 62 & $100 \%$ \\
\hline
\end{tabular}

Dari tabel 1 diatas dapat dilihat bahwa jumlah responden sebanyak 62 responden, yang mengalami kejadian gizi buruk 19 responden dibandingkan ibu hamil yang mengalami gizi baik 43 responden.

\section{Antenatal care}

Pada penelitian ini antenatal care responden dikelompokkan menjadi 2 kategori yaitu lengkap ( bila 10T dan kunjungan ANC lengkap sesuai trimesternya) dan tidak lengkap (bila 10T dan kunjungan ANC tidak lengkap sesuai trimesternya) yang akan diuraikan pada tabel 2 :

Tabel 2 Distribusi Frekuensi Responden Berdasarkan Antenatal Care Di Puskesmas Gandus Palembang Tahun 2016

\begin{tabular}{llcc}
\hline No & \multicolumn{1}{c}{$\begin{array}{c}\text { Antenatal } \\
\text { Care }\end{array}$} & $\begin{array}{c}\text { Jumlah } \\
\text { (n) }\end{array}$ & $\begin{array}{c}\text { Persentase } \\
(\boldsymbol{\%})\end{array}$ \\
\hline $\mathbf{1}$ & Lengkap & 41 & 66,1 \\
$\mathbf{2}$ & Tidak & 21 & 33,9 \\
& lengkap & & \\
\hline & Jumlah & 62 & 100 \\
\hline
\end{tabular}

Dari tabel 2 diatas dapat dilihat bahwa jumlah responden sebanyak 62 orang yang antenatal carenya lengkap lebih tinggi 41 $(66,1 \%)$ dibandingan dengan responden yang antenatal carenya rendah $21(33,9 \%)$.

\section{Hipertensi dalam Kehamilan}

Dari hasil penelitian ini terdapat terdapat 62 responden dan hipertensi dalam kehamilan dikelompokkan menjadi 2 kategori yaitu Ya (Jika tekanan darah $\geqq 140 / 90 \mathrm{mmHg}$ ) dan Tidak (jika tekanan darah < 140/90 mmHg) yang akan diuraikan pada tabel 3 : 
Jurnal Kebidanan : Jurnal Medical Science Ilmu Kesehatan Akademi Kebidanan Budi Mulia Palembang Volume.8 No.2, Desember 2018

Tabel 3 Distribusi Frekuensi Responden Berdasarkan Hipertensi Dalam Kehamilan Di Puskesmas Gandus Palembang Tahun 2016

\begin{tabular}{llcc}
\hline No & $\begin{array}{c}\text { Hipertensi } \\
\text { dalam } \\
\text { kehamilan }\end{array}$ & $\begin{array}{c}\text { Jumlah } \\
(\mathbf{n})\end{array}$ & $\begin{array}{c}\text { Persentase } \\
(\mathbf{\%})\end{array}$ \\
\hline $\mathbf{1}$ & Tidak & 52 & 83,9 \\
$\mathbf{2}$ & Ya & 10 & 16,1 \\
\hline & Jumlah & 62 & 100 \\
\hline
\end{tabular}

Dari tabel 3 diatas dapat dilihat bahwa dari jumlah responden yang Ya 10 orang $(16,1 \%)$ lebih rendah dari responden yang Tidak 52 orang $(83,9 \%)$.

\section{Riwayat Penyakit Ibu}

Dari hasil penelitian ini terdapat terdapat 62 responden dan riwayat penyakit ibu dikelompokkan menjadi 2 kategori yaitu ada (bila ibu ada riwayat penyakit) dan tidak ada ( bila ibu tidak memiliki riwayat penyakit) yang akan diuraikan pada tabel 4 :

Tabel 4 Distribusi Frekuensi Responden Berdasarkan Riwayat Penyakit Ibu Di Puskesmas Gandus Palembang Tahun 2016

\begin{tabular}{cccc}
\hline No & $\begin{array}{c}\text { Riwayat } \\
\text { penyakit } \\
\text { ibu }\end{array}$ & $\begin{array}{c}\text { Jumlah } \\
(\mathbf{n})\end{array}$ & $\begin{array}{c}\text { Persentase } \\
(\boldsymbol{\%})\end{array}$ \\
\hline $\mathbf{1}$ & Tidak ada & 58 & 93,5 \\
$\mathbf{2}$ & Ada & 4 & 6,5 \\
\hline & Jumlah & 62 & 100 \\
\hline
\end{tabular}

Dari tabel 4 diatas dapat dilihat bahwa dari jumlah responden yang Tidak 58 orang $(93,5 \%)$ dan untuk jumlah responden yang Ya 4 orang $(6,5 \%)$.

\section{b. Analisa Bivariat}

Analisis ini dilakukan untuk mengetahui hubungan antara variabel independen (antenatal care, hipertensi dalam kehamilan, riwayat penyakit ibu) dengan variabel dependen (status gizi). Dengan batas kemaknaan jika $p$ value $<\alpha$ $=0,05$ artinya ada hubungan yang bermakna antara variabel independen dan dependen.

\section{Hubungan Antenatal care dengan Gizi ibu} Hamil

Pada penelitian ini antenatal care responden dikelompokkan menjadi 2 kategori yaitu lengkap ( bila 10T dan kunjungan ANC lengkap sesuai trimesternya) dan tidak lengkap (bila 10T dan kunjungan ANC tidak lengkap sesuai trimesternya) sedangkan, Gizi Ibu Hamil dikategorikan menjadi dua yaitu Standar (2 kategori yaitu : Gizi Baik (Bila LILA >23,5 dan berat badan $\geq 10-12 \mathrm{~kg}$ ), dan Gizi Kurang (Apabila LILA $<23,5 \mathrm{~cm}, \mathrm{BB} \leq 10 \mathrm{Kg}$ ) dapat dilihat pada tabel 5:

Tabel 5 Distribusi Responden Berdasarkan Antenatal Care Dengan Status Gizi Ibu Hamil Di Puskesmas Gandus Tahun 2016

\begin{tabular}{|c|c|c|c|c|c|c|c|c|}
\hline \multirow{3}{*}{ No } & \multirow{3}{*}{$\begin{array}{c}\text { Antenatal } \\
\text { Care }\end{array}$} & \multicolumn{4}{|c|}{ Gizi Ibu Hamil } & \multirow{2}{*}{\multicolumn{2}{|c|}{ Jumlah }} & \multirow{3}{*}{$\begin{array}{l}\text { Tingkat } \\
\text { Kemakn } \\
\text { aan }\end{array}$} \\
\hline & & \multicolumn{2}{|c|}{ Gizi Baik } & \multicolumn{2}{|c|}{$\begin{array}{c}\text { Gizi } \\
\text { Kurang }\end{array}$} & & & \\
\hline & & $\mathbf{n}$ & $\%$ & $\mathbf{n}$ & $\%$ & $\mathbf{N}$ & $\%$ & \\
\hline 1. & Lengkap & 34 & 82,9 & 7 & 17,1 & 41 & 100 & \\
\hline 2. & $\begin{array}{l}\text { Tidak } \\
\text { Lengkap }\end{array}$ & 9 & 42,9 & 12 & 57,1 & 21 & 100 & $\begin{array}{c}\mathrm{P} \text { value }= \\
0,03\end{array}$ \\
\hline \multicolumn{2}{|c|}{ Jumlah } & 43 & - & 19 & - & 62 & 100 & \\
\hline
\end{tabular}

Dari tabel 5 diatas dapat diketahui bahwa dari 41 responden dengan antenatal care lengkap yang mengalami status gizi sebanyak 34 orang $(82,9 \%)$ lebih besar dibandingkan dengan status gizi kurang sebanyak 7 orang $(17,1 \%)$. Sedangkan dari 21 responden dengan antenatal care tidak lengkap yang mengalami status gizi baik sebanyak 9 orang $(42,9 \%)$ lebih kecil dibandingkan dengan status gizi kurang sebanyak 12 orang $(57,1 \%)$.

Hasil uji statistik Chi - Square dan $\alpha=$ 0,05 diperoleh $p$ value $=0,03$ berarti ada hubungan yang bermakna antara antenatal care dengan status gizi. Dengan demikian hipotesis yang menyatakan ada hubungan antara antenatal care dengan status gizi terbukti secara statistik.

\section{Hubungan Hipertensi dalam kehamilan dengan Status Gizi Ibu Hamil}

Dari hasil penelitian ini terdapat terdapat 62 responden dan hipertensi dalam kehamilan dikelompokkan menjadi 2 kategori yaitu Ya (Jika tekanan darah $\geqq 140 / 90 \mathrm{mmHg}$ ) dan Tidak (jika tekanan darah < 140/90 $\mathrm{mmHg}$ ) sedangkan, Gizi Ibu Hamil dikategorikan menjadi dua yaitu Standar (2 kategori yaitu : Gizi Baik (Bila LILA $>23,5$ dan berat badan $\geq 10-12 \mathrm{~kg}$ ), dan Gizi Kurang (Apabila LILA $<23,5 \mathrm{~cm}, \mathrm{BB} \leq 10$ $\mathrm{Kg})$ Hasil uji statistik dapat dilihat pada tabel 6 :

Tabel 6 Distribusi Responden Berdasarkan Hipertensi Dalam Kehamilan Dengan Status Gizi Ibu Hamil Di Puskesmas Gandus Tahun 2016 
Jurnal Kebidanan : Jurnal Medical Science Ilmu Kesehatan Akademi Kebidanan Budi Mulia Palembang Volume.8 No.2, Desember 2018

\begin{tabular}{|c|c|c|c|c|c|c|c|c|}
\hline \multirow{3}{*}{ No } & \multirow{3}{*}{$\begin{array}{l}\text { Hipertensi } \\
\text { dalam } \\
\text { kehamilan }\end{array}$} & \multicolumn{4}{|c|}{ Status Gizi Ibu Hamil } & & \multirow[b]{2}{*}{ mlah } & \multirow{2}{*}{$\begin{array}{c}\text { Ting } \\
\text { kat } \\
\text { Kem } \\
\text { akna } \\
\text { an }\end{array}$} \\
\hline & & \multicolumn{2}{|c|}{ Gizi Baik } & \multicolumn{2}{|c|}{$\begin{array}{c}\text { Gizi } \\
\text { Kurang }\end{array}$} & & & \\
\hline & & $n$ & $\%$ & $\mathrm{n}$ & $\%$ & $\mathbf{N}$ & $\%$ & \\
\hline 1. & Tidak & 39 & 75 & 13 & 25 & 52 & 100 & $\mathrm{P}$ \\
\hline 2. & Ya & 4 & 40 & 6 & 60 & 10 & 100 & Value \\
\hline & Jumlah & 43 & & 19 & & 62 & & $=0,68$ \\
\hline
\end{tabular}

Dari tabel 6 diatas dapat diketahui bahwa

dari 10 responden dengan hipertensi dalam kehamilan yang kategori ya sebanyak $4(40 \%)$ yang berstatus gizi baik lebih kecil dibandingkan dengan status gizi kurang 6 orang (60\%). Sedangkan dari 52 responden dengan kategori tidak yang berstatus gizi baik berjumlah 39 orang (75\%) lebih besar dibandingkan dengan status gizi kurang sebanyak 13 orang (25\%).

Hasil uji statistik Chi-Square dan $\alpha=0,05$ diperoleh $\rho$ value $=0,68$ berarti tidak ada hubungan antara hipertensi dalam kehamilan dengan status gizi secara statistik.

\section{Hubungan Riwayat Penyakit Ibu dengan Status Gizi Ibu Hamil}

Dari hasil penelitian ini terdapat terdapat 62 responden dan riwayat penyakit ibu dikelompokkan menjadi 2 kategori yaitu ada (bila ibu ada riwayat penyakit) dan tidak ada ( bila ibu tidak memiliki riwayat penyakit) sedangkan, Gizi Ibu Hamil dikategorikan menjadi dua yaitu Standar (2 kategori yaitu : Gizi Baik (Bila LILA >23,5 dan berat badan $\geq 10-12$ $\mathrm{kg}$ ), dan Gizi Kurang (Apabila LILA < 23,5 cm , $\mathrm{BB} \leq 10 \mathrm{Kg})$ Hasil uji statistik dapat dilihat pada tabel 7 :

Tabel 7 Distribusi Responden Berdasarkan Riwayat Penyakit ibu Dengan Status Gizi Ibu Hamil Di Puskesmas Gandus Tahun 2016

\begin{tabular}{|c|c|c|c|c|c|c|c|c|}
\hline \multirow{3}{*}{ No } & \multirow{3}{*}{$\begin{array}{c}\text { Hipertensi } \\
\text { dalam } \\
\text { kehamilan }\end{array}$} & \multicolumn{4}{|c|}{ Status Gizi Ibu Hamil } & & \multirow[b]{2}{*}{ mlah } & \multirow{2}{*}{$\begin{array}{c}\text { Ting } \\
\text { kat } \\
\text { Kem } \\
\text { akna } \\
\text { an } \\
\end{array}$} \\
\hline & & \multicolumn{2}{|c|}{ Gizi Baik } & \multicolumn{2}{|c|}{$\begin{array}{c}\text { Gizi } \\
\text { Kurang }\end{array}$} & & & \\
\hline & & $\mathbf{n}$ & $\%$ & $\mathbf{n}$ & $\%$ & $\mathbf{N}$ & $\%$ & \\
\hline 1. & Tidak Ada & 42 & 72,4 & 16 & 27,6 & 58 & 100 & $\mathrm{P}$ \\
\hline 2. & Ada & 1 & 25 & 3 & 75 & 4 & 100 & Valu \\
\hline & Jumlah & 43 & & 19 & & 62 & & $=0,68$ \\
\hline
\end{tabular}

Dari tabel 7 diatas dapat diketahui bahwa

dari 4 responden dengan riwayat penyakit ibu yang kategori ada sebanyak 1 (25\%) yang berstatus gizi baik lebih kecil dibandingkan dengan gizi kurang sebanyak 3 orang $(75 \%)$. Sedangkan dari 58 responden dengan riwayat penyakit ibu yang kategori tidak ada sebanyak 42 orang $(72,4 \%)$ yang berstatus gizi baik lebih

besar dibandingkan dengan gizi kurang sebanyak 16 orang $(27,6 \%)$.

Hasil uji statistik Chi-Square dan $\alpha=0,05$ diperoleh $\rho$ value $=0,153$ berarti tidak ada hubungan antara riwayat penyakit ibu dengan status gizi secara statistik.

\section{PEMBAHASAN}

\section{Status Gizi Ibu Hamil}

Sampel dalam penelitian ini adalah seluruh ibu hamil yang berkunjung ke Puskesmas Gandus Palembang pada bulan Juli - Agustus tahun 2016 sebanyak 62 responden. Diketahui responden yang berstatus gizi baik sebanyak 43 $(69,4 \%)$ orang dan yang berstatus gizi kurang sebanyak $19(30,6 \%)$ orang.

\section{Antenatal care dengan Status Gizi Ibu Hamil}

Pada penelitian ini terdapat 62 responden dan hipertensi dalam kehamilan yang dikelompokkan menjadi 2 kategori yaitu Ya (Jika tekanan darah $\geqq 140 / 90 \mathrm{mmHg}$ ) dan Tidak (jika tekanan darah < 140/90 $\mathrm{mmHg}$ ).

Dari hasil analisis univariat bahwa dari jumlah responden yang Ya 10 (16,1\%) lebih rendah dari responden yang Tidak $52(83,9 \%)$.

Dari hasil analisi bivariat diketahui bahwa dari 41 responden dengan antenatal care lengkap yang mengalami status gizi sebanyak 34 orang $(82,9 \%)$ lebih besar dibandingkan dengan status gizi kurang sebanyak 7 orang $(17,1 \%)$. Sedangkan dari 21 responden dengan antenatal care tidak lengkap yang mengalami status gizi baik sebanyak 9 orang $(42,9 \%)$ lebih kecil dibandingkan dengan status gizi kurang sebanyak 12 orang $(57,1 \%)$.

Hasil uji statistik Chi - Square dan $\alpha=$ 0,05 diperoleh $p$ value $=0,03$ berarti ada hubungn yang bermakna antara antenatal care dengan status gizi. Dengan demikian hipotesis yang menyatakan ada hubungan antara antenatal care dengan status gizi terbukti statistik.

Hasil penelitian ini sejalan dengan penelitian sebelumnya yang dilakukan mardiatun dkk (2013) di provinsi Nuta Tenggara Barat dan di Daerah Istimewa Yogyakarta menyatakan bahwa terdapat hubungan antara ANC dengan status gizi di NTB dengan nilai OR 1,793. Hasil uji statistik Chi Square didapatkan nilai $\mathrm{p}(0,000)<0,05$ sehingga terdapat hubungan antara ANC dengan status gizi di Yogyakarta dengan nilai OR 0,442.

Antenatal Care adalah pemeriksaan kesehatan yang dilakukan untuk memeriksa keadaan ibu dan janin secara berkala yang diikuti 
dengan upaya koreksi terhadap penyimpangan yang ditemukan (Rukiyah dkk, 2013)

Dengan melakukan ANC, dapat mendeteksi secara dini kelainan yang terdapat pada ibu dan janin dengan memberikan pendidikan kesehatan tentang pemberian gizi yang baik melalui 10T pemeriksaan ANC kehamilan yang terdiri dari : 1) Timbang berat badan dan ukur tinggi badan, 2) Ukur tekanan darah, 3) Nilai status gizi, 4) Ukur tinggi fundus uteri, 5) Tentukan presentasi janin, 6) Skrining status imunisasi TT, 7) Pemberian tablet Fe, 8) Test laboratorium, 9) Tata laksana kasus, 10) Temu wicara(konseling) (Depkes, 2010). ANC yang dilakukan ibu hamil dengan penekanan yang didapatkan pada saat pemeriksaan kehamilan (10T) berdasarkan penelitian ini dapat diharapkan mencegah status gizi yang buruk pada ibu hamil.

\section{Hipertensi dalam Kehamilan dengan Status Gizi Ibu Hamil}

Dari hasil penelitian ini terdapat terdapat 62 responden dan hipertensi dalam kehamilan dikelompokkan menjadi 2 kategori yaitu Ya (Jika tekanan darah $\geqq 140 / 90 \mathrm{mmHg}$ ) dan Tidak (jika tekanan darah $<140 / 90 \mathrm{mmHg}$ ).

Dari hasil analisis univariat bahwa dari jumlah responden yang Ya $10 \quad(16,1 \%)$ lebih rendah dari responden yang Tidak $52(93,9 \%)$.

Dari hasil analisis bivariat diketahui bahwa dari 10 responden dengan hipertensi dalam kehamilan yang kategori ya sebanyak 4 (40\%) yang berstatus gizi baik lebih kecil dibandingkan dengan status gizi kurang 6 orang (60\%). Sedangkan dari 52 responden dengan kategori tidak yang berstatus gizi baik berjumlah 39 orang $(75 \%)$ lebih besar dibandingkan dengan status gizi kurang sebanyak 13 orang $(25 \%)$.

Hasil uji statistik Chi-Square dan $\alpha=0,05$ diperoleh $\rho$ value $=0,68$ berarti tidak ada hubungan yang bermakna antara hipertensi dalam kehamilan dengan status gizi . Dengan demikian hipotesis yang menyatakan tidak ada hubungan antara hipertensi dalam kehamilan dengan status gizi secara statistik.

Hipertensi atau tekanan darah tinggi merupakan terjadinya peningkatan tekanan darah, hingga hal ini dapat membuat adanaya tekanan dan merusak dinding arteri di pembuluh darah. Seseorang dikatakan mengalami hipertensi jika tekanan darahnya di atas 140/90 $\mathrm{mmHg}$ (Manuaba, 2012).

Hipertensi pada saat hamil akan berdampak pada ibu dan janin. Dengan tingginya tekanan darah maka arus darah akan mengalami gangguan begitu pula pada organ ginjal, hati, otak, rahim dan juga plasenta.Ibu hamil yang menderita hipertensi akan berdampak pada janin dimana nutrisi dan oksigen akan mengalami kondisi abnormal. Hal ini disebabkan karena pembuluh darah akan mengalami penyempitan. Bagi ibu sendiri pun harus membatasi pola makannya agar tidak memperburuk hipertensinya

\section{Riwayat Penyakit Ibu dengan Status Gizi Ibu Hamil}

Dari hasil penelitian ini terdapat terdapat 62 responden dan riwayat penyakit ibu dikelompokkan menjadi 2 kategori yaitu ada (bila ibu ada riwayat penyakit) dan tidak ada ( bila ibu tidak memiliki riwayat penyakit).

Dari hasil analisis univariat dapat dilihat bahwa dari jumlah responden yang Ya $4(6,5 \%)$ dan untuk jumlah responden yang Tidak $58(93,5$ $\%)$.

Dari hasil analisis bivariat diketahui bahwa dari 4 responden dengan riwayat penyakit ibu yang kategori ada sebanyak $1(25 \%)$ yang berstatus gizi baik lebih kecil dibandingkan dengan gizi kurang sebanyak 3 orang (75\%). Sedangkan dari 58 responden dengan riwayat penyakit ibu yang kategori tidak ada sebanyak 42 orang $(72,4 \%)$ yang berstatus gizi baik lebih besar dibandingkan dengan gizi kurang sebanyak 16 orang $(27,6 \%)$.

Hasil uji statistik Chi-Square dan $\alpha=0,05$ diperoleh $\rho$ value $=0,153$ berarti tidak ada hubungan yang bermakna antara riwayat penyakit ibu dengan status gizi . Dengan demikian hipotesis yang menyatakan tidak ada hubungan antara riwayat penyakit ibu dengan status gizi terbukti statistik.

Riwayat penyakit merupakan penyakitpenyakit yang pernah diderita ibu yang memiliki risiko terhadap kehamilan dan persalinan saat ini yang tercantum dalam status ibu(Adriani, 2013).

Status gizi atau tingkat konsumsi pangan merupakan bagian penting dari status kesehatan seseorang. Tidak hanya status gizi yang mempengaruhi kesehatan seseorang, tetapi status kesehatan juga mempengaruhi status gizi.

Penanganan penyakit-penyakit harus diperhatikan dalam pemberian obat-obatan dan nutrisi makanannya. Karena dengan pemberian obat-obatan dan makanan yang salah dapat memberikan efek terutama kepada janin dan ibu. Sehingga kita harus mengetahui jenis obatobatan yang boleh diberikan kepada ibu hamil 
Jurnal Kebidanan : Jurnal Medical Science Ilmu Kesehatan Akademi Kebidanan Budi Mulia Palembang Volume.8 No.2, Desember 2018

dan juga yang tidak boleh diberikan pada ibu hamil. Jangan sampai kita bermaksud memberikan pengobatan untuk kesembuhan tapi malah menyebabkan efek teratogenik pada janin (Almizah, 2014).

\section{KESIMPULAN}

Dari hasil penelitian yang dilakukan di Puskesmas Gandus Palembang tahn 2016 dengan jumlah responden 62 orang, mengenai variabel dependen (status gizi) dan variabel independen (antenatal care, hipertensi dalam kehamilan, riwayat penyakit ibu) dapat disimpulkan bahwa :

1. Ada hubungan yang bermakna antara Antenatal Care ibu secara parsial dengan status gizi di Puskesmas Gandus Palembang tahun 2016.

2. Tidak ada hubungan antara hipertensi dalam kehamilan secara parsial dengan status gizi di Puskesmas Gandus Palembang tahun 2016

3. Tidak ada hubungan antara riwayat penyakit ibu secara parsial dengan status gizi di Puskesmas Gandus Palembang tahun 2016.

\section{SARAN}

\section{Kepada Pemimpin Puskesmas Gandus} Palembang

Diharapkan hasil penelitian ini dapat dijadikan masukan baik dalam menyusun rencana strategi serta pelaksanaan dalam memberikan pelayanan langsung pada pasien, sehingga mutu dan kualitas pelayanan lebih ditingkatkan lagi.

\section{Kepada Peneliti dan Peneliti yang Akan} Datang

Diharapkan dapat memilih variabel yang lebih banyak yang berhubungan dengan status gizi serta populasi dan sampel yang lebih besar.

\section{DAFTAR PUSTAKA}

Atika dan Siti. 2009. Gizi Untuk Kebidanan. Balai Penerbit :Nuha Medika. Yogyakarta

Dinkes Palembang. 2014. Profil Kesehatan Kota Palembang tahun 2014. Palembang

Manuaba, IBG. 2012. Ilmu Kebidanan Penyakit Kandungan dan Keluarga Berencana untuk Pendidikan Bidan. Jakarta: EGD

Merryana dan Bambang. 2014. Gizi Dan Kesehatan Balita. Kencana Prenadamedia Group. Jakarta

Notoatmodjo, Soekidjo. 2012. Metodelogi Penelitian dan Kesehatan. Rineka Cipta. Jakarta, Indonesia

Profil Puskesmas Gandus Palembang, 2015

Rohan dan Siyoto. 2013.Buku Ajar:Kesehatan Reproduksi. Nuha Medika. Yogyakarta
Rukiyah. dkk. 2013. Asuhan Kebidananl Kehamilan.. Trans Info Media. Jakarta

Aditya. 2015. "bayi berat lahir rendah di Indonesia masih

tinggi”. TribunJogja.

http://www.tribunnews.com/tag/bayi-

berat-lahir-rendah-di-indonesia-masihtinggi/diakses tanggal 26 mei 2016

Chandaranita. 2010.analisis faktor yang mempengaruhi kekurangan energy kronis pada ibu hamil.file:///C:/Users/User/Desktop/Kebi danan\%20Lisa/17-48-1-PB.pdf/diakses tanggal 17 mei 2016

Driani. Ayu. 2013. Hubungan Asupan Gizi Dan Status Gizi Ibu Hamil Trimester III Dengan Berat Badan Lahir Bayi Di Wilayah Kerja Puskesmas Suruh.Jurnal ilmu Kebidanan Vol.5 No.1 2013.

Iswahyudi. 2015. 'Banyak Ibu Hamil Di Indonesia Kekurangan Gizi”. Tribunsumsel. http://sumsel.tribunnews.com/2015/10/05/ banyak-ibu-hamil-di-indonesiakekurangan-gizi/diakses tanggal 26 mei $\underline{2016}$

Hardiani, Ratna. 2012. Motivasi Dan Kepatuhan Kunjungan Antenatal Care (Anc) Pada Ibu Hamil Trimester III.Jurnal Keperawatan vol.3 No.2 2012. file:///C:/Users/User/Desktop/Kebidanan \%20Lisa/data\%20lisa/file/000.pdf diakses tanggal 20 mei 2016

Herman. 2014. Kekuragan gizi masih menjadi Masalah ibu hamil di Indonesia. http://www.beritasatu.com/kesehatan/23 6742-kekurangan-gizi-masih-jadimasalah-ibu-hamil-diindonesia.html/diakses tanggal 26 mei $\underline{2016}$

Maharani. 2015. "Pahami Pentingnya Gizi Ibu dan Bayi". Kompas

http://health.kompas.com/read/2015/05/15 1094019023/Pahami.Pentingnya.Gizi.Ibu. dan.Bayi/diakses pada tanggal $26 \mathrm{mei}$ 2016

Muliawati. 2013. Faktor Penyebab Ibu Hamil Kurang Energi Kronis Di Puskesmas Sambi Kecamatan Sambi Kabupaten Boyolali Tahun 2012. Jurnal ilmiah Infokes, vol.3 No.3 2013. http://repository.usu.ac.id/bitstream/12345 6789/14594/1/031000306.pdf. Diakses taggal 20 mei 2016

Rohmatul. 2011.Gizi dalam kespro. http://rohmatulazifa.blogspot.co.id/p/cstat us-pengaruh-gizi-dalam-kehamilan.html/ 
Jurnal Kebidanan : Jurnal Medical Science Ilmu Kesehatan Akademi Kebidanan Budi Mulia Palembang Volume.8 No.2, Desember 2018

Diakses tanggal 25 mei 2016. Diakses tanggal 16 juli 2016

Yoga, 2015. Kanker dan kehamilan. http://www.cancer.net/coping/emotionaland-physical-matters/sexual-andreproductive-health/cancer-duringpregnancy. Diakses tanggal 16 juli 2016

Dewi. 2012 pengaruh pola makan dan status gizi terhadap kejadian hipertensi pada ibu hamil di RSU Tanjung Pura Kabupaten Langkat tahun 2012. http://repository.usu.ac.id/bitstream/1234 56789/37235/4/Chapter\%20I.pdf.

Diakses tanggal 17 juli 2016

Khairunnisa. 2014._Status Kesehatan Yang Mempengaruhi Kehamilan. http://khairunnisasyuhada.blogspot.com/ 2014/01/status-kesehatan-yangmempengaruhi.html. diakses tanggal 17 juli

Gelmani Rabiah. 2015. Pola Makan Untuk Penderita Penyakit Ginjal. http://segiempat.com/sehat/pola-hidupsehat/pola-makan-untuk-penderitapenyakit-ginjal/. Diakses tanggal 30 agustus 2016. 
